\title{
A Stuttering Therapy Programme with Spastic Dysphonia - a Single Case Study
}

\author{
Ingrid Meyers BA (Sp \& H Th) (Witwatersrand) \\ Speech Therapy Department Baragwanath Hospital \\ Denise Anderson BA (Sp \& H Th) (Witwatersrand) \\ Department of Speech Pathology and Audiology, \\ University of the Witwatersrand, Johannesburg
}

\section{ABSTRACT}

This study was motivated by reported similarities in vocal tract dynamics in stuttering and spastic dysphonia. The effects of a stuttering therapy programme with an adult with spastic dysphonia were observed. Subjective and objective measures obtained pre- and posttherapeutically included a qualitative analysis, laryngographic tracings, and fiberoptic examinations. Results showed subtle improvements on all measures suggesting improved laryngeal behaviours. Findings are discussed in relation to therapeutic utility.

\section{OPSOMMING}

Die motivering vir hierdie ondersoek is gebasseer op die ooreenkomste t.o.v. die dinamiek van die vokale gang tydens hakkel en spastiese disfonie. Die uitwerking van 'n terapieprogram vir hakkel wat uitgevoer is op 'n pasiënt met spastiese disfonie, is waargeneem. Subjektiewe en objektiewe metings is voor-en na-terapeuties van laringografiese afdrukke, fiberoptiese ondersoeke en van 'n kwalitatiewe analise ver$k r y$. Resultate dui op 'n subtiele verbetering op alle metings, wat verbeterde laringale werking aandui. Die bevindinge word bespreek t.o.v. kliniese bruikbaarheid.

Of all the human voice disorders, the syndrome of adductor spastic dysphonia has remained the most mysterious, the most poorly understood, and the most resistant to effective treatment, (Boone 1972; Aronson 1980; Reich and Till 1983). Spastic dysphonia is a rare disorder and literature on the subject is limited, which has led to some confusion with regard to treatment (Wolk, 1980). Yet most authorities agree on its poor response to therapy procedures.

The disorder, first described by Traube in 1871 is characterized by "a strained, creaking, choked vocal attack and a tense squeezed voice accompanied by extreme tension of the entire phonatory system." (Luchsinger and Arnold 1965). Various terms have been used to describe the disorder of spastic dysphonia. It has been referred to as 'glottal spasms', 'stammering of the vocal cords' and 'Iaryngeal stuttering', and has been parallelled to the disorder of stuttering by McCall (1975) and Salamy and Sessions (1980). Stuttering is a more common disorder, and the age of onset and sex distribution are well defined. The two disorders can, however be likened in terms of their variability, development and course, etiological controversy and history of therapeutic failure with high rates of symptom relapse (Ingham and Andrews 1973; Aronson 1980; Salamy and Sessions 1980).

Perhaps the abnormality in the physiology of the larynx for stuttering and spastic dysphonia could be considered a major similarity. McCall (1975) found that similarities between spastic dysphonia and the stuttering block included muscle spasms, disturbed muscle tone and involuntary movements e.g. tremor, with normal laryngeal structures evident on laryngologic examination.

Die Suid-Afrikaanse Tydskrif vir Kommunikasieafivykings, Vol. 32, 1985
The past decade has brought about a dramatic transition in the theoretical foundation and purpose in the treatment of stuttering. Based on the factors which induce fluency in stutterers, remediation has shifted to manipulation of phonation utilizing behaviour modification techniques as a vehicle for establishing fluency (Shames and Florance 1980). Common to all 'fluency-based' programmes are smooth initiation of phonation, decreased rate and continuous phonation and breath flow which facilitates co-ordination of the vocal folds concurrent with the execution of articulatory gestures (Miller 1982). Schwartz (1976) felt that it was the reduction in stress on the cords which facilitated their laxing and lengthening and enabled their greater bulk to vibrate.

The literature on spastic dysphonia does not reflect the same advances regarding treatment approaches. While some authorities have described similar techniques to those constituting 'fluency-based' programmes, no-one has as yet integrated these techniques into a unified therapy programme. In view of the limited investigations into the field of spastic dysphonia, and of the need to explore new avenues for treatment, the writers decided to investigate the effects of a fluency-based programme (developed for stutterers) by Shames and Florance (1980) on a subject with spastic dysphonia.

\section{METHOD}

\section{SUBJECT}

The subject, S, was an English speaking adult male, aged 34 years whose profession involved much public speaking. His voice problem

(C) SASHA 1985 
began at the age of twenty and since that time he has received treatment in the form of psychotherapy, medication and traditional voice therapy, all of which have provided little relief from the disorder. No family history of spastic dysphonia has been reported. S's voice was characterized by breaks in phonation caused by an intermittent, strained-strangled and highly tense voice with reduced modal pitch and voice intensity. Reflex actions of phonation were intact and thus laughing and coughing were carried out normally. The symptoms became more prominent as the communicative demands of speech were increased.

\section{PROCEDURE}

\section{PRE-INTERVENTION VOICE MEASURES}

Pre-intervention samples were obtained over two days prior to the initiation of treatment. These samples were analyzed subjectively and objectively. All measures were obtained in a sound proof recording room, in the phonetic laboratory, Department of Linguistics at the University of the Witwatersrand, Johannesburg.

The three voice samples included:

(1) Sustained phonation of (i:) for 5 secs.

(2) Reading the first paragraph of the Fairbanks Rainbow Passage (Fairbanks 1940).

(3) A spontaneous speech sample.

\section{a) Subjective evaluation}

The voice was recorded on the Uher 4200 stereo tape recorder. Two independent raters judged the severity of the voice samples. A rating scale adapted from Aronson et al. (1968) and Wilson (1979) was utilized for the qualitative analysis (see Appendix I). Severity was measured by classifying the subject's voice on a severity continuum based on Aronson et al (1968). The two raters who rated blind as to whether the recordings were pre- or post-therapeutic, calculated the frequency of occurrence of strained, squeezed, staccato or effortful phonation (Aronson 1980) for both reading and spontaneous speech. This constituted a measure of percentage and strained-strangled syllables (\%SS), which was to be used as an equivalent of percentage stuttered syllables used for stutterers. This has been found to be a good indicator for treatment effectiveness (Perkins et al. 1974).

Finally, a speaking and reading rate was calculated by counting the number of syllables spoken in one minute. This was to constitute a measure of syllables per minute (SPM), which is necessary for determining the desired rate to be reached in the therapy programme (Shames and Florance, 1980).

\section{b) Objective Evaluation}

The following measures were obtained by the principal phonetician in the Department of Linguistics, University of the Witwatersrand:

i) Laryngographic Tracings. Wechsler (1977) writes that laryngographic tracings provide a qualitative description of the voice, and show preferred qualitative estimates of vocal fold regularity. Using a Fourcin laryngograph and voicescope, the laryngographic procedure was carried out in the manner described by Wechsler (1977) and Kelman (1981).

Hirano (1981) writes that tracings should be obtained from both the steady position of sustained vowels, and the transitional phases of phonation. The output of the laryngo- graph and voicescope was simultaneously recorded on a Mingograf inkjet recorder.

Each laryngograph was segmented into phonation stretches of $100 \mathrm{~m} / \mathrm{sec}$. The stretches were analyzed according to preselected categories from the features presented by Wechsler (1977) and Kelman (1981), and a frequency count based on visualizing these categories was used (see Appendix II).

ii) Fiberoptic Examination. This measure was employed to observe the laryngeal behaviours directly during connected speech. Aronson (1980) and Chapey and Salzberg (1981) maintain that fiberoptic examination is the only means by which one can observe and describe vocal fold behaviour, as well as co-ordinate the visual and auditory aspects of voice production. A flexible fiberscope connected by a c-mount adaptor to a type 4AZ Olympus OMI camera was used for the fiberoptic examination. The tape recorder was prepared to run concurrently with the examination so as to record all utterances. The vocal folds were examined at rest, during deep breathing and during a spontaneous speech sample. They were also examined during the prolongation of (i:) at a comfortable loudness and pitch level. The audio tape recordings corresponding to each slide, derived from the fiberoptic examination, were transcribed and two independent raters judged the perceptual characteristics of each slide.

\section{INTERVENTION PROGRAMME}

The intervention was carried out daily by one of the writers over a 3-week period. The programme employed was the 'stutter-free' speech programme (Shames and Florance 1980). Based on the principles of operant conditioning to modify behaviour, the programme involves five overlapping stages which are systematically scheduled. The client is taught to deliberately control the rate of speech and to control the segmenting of speech acts so that there is continuous phonation and airflow between and within words. Continuous phonation with normal rate and prosody become the goals for treatment. Monitored speech is emphasized and the new speaking skills are transferred into the patient's entire talking day by moving up a situation hierarchy. Unmonitored speech eventually replaces monitored speech (Shames and Florance 1980).

The following alterations were made to Shames and Florance's (1980) original 'stutter-free' speech programme:

- The desired parameter of fluency was exchanged with that of efficient voice.

- The passive airflow technique, described by Schwartz (1976) was used to assist $\mathbf{S}$. in initiating phonation.

The rationale for, and nature of the treatment programme was explained to $S$., and both reading and speaking were practised at varying rates of speech. A home programme was included as an adjunct to the therapy programme.

\section{Post-Intervention Measures}

Over the two days immediately after the therapy programme, both subjective and objective evaluations were carried out following the identical procedures to that of the pre-intervention evaluation.

\section{RESULTS}

Interrater reliability was high for all measures (93-100\%). The overall severity of the voice and the samples corresponding to the fiberoptic slides were discussed until some agreement was reached. 
A Stuttering Therapy Programme with Spastic Dysphonia - a Single Case Study

SUBJECTIVE EVALUATION

a) QUALITATIVE ANALYSIS AND OVERALL VOCAL SEVERITY:

Table 1 indicates a summary of the results obtained for all three voice samples pre- and post-therapeutically.

Table 1 Mean ratings from the pre- and post-therapy qualitative analysis of 10 vocal parameters rated on a 7 pt. equal interval rating scale with $1=$ Normal and $7=$ Deviant, as well as overall severity of the vocal pattern.

\begin{tabular}{|c|c|c|c|c|c|c|c|}
\hline \multirow{2}{*}{\multicolumn{2}{|c|}{ Vocal Parameter }} & \multicolumn{2}{|c|}{ /i:/ } & \multicolumn{2}{|c|}{ Reading } & \multicolumn{2}{|c|}{$\begin{array}{l}30 \text { Secs. } \\
\text { Spontaneous } \\
\text { Speech }\end{array}$} \\
\hline & & Pre & Post & Pre & Post & Pre & Post \\
\hline 1) & Laryngeal Tension & 6 & 1 & 7 & 5,5 & 7 & 3 \\
\hline 2) & Laryngeal Tone Rough/Hoarse & 4 & 1,5 & 2,5 & 3 & 3 & 3,5 \\
\hline 3) & Voice Tremor & 6 & 4 & 3 & 3,5 & 4,5 & 4 \\
\hline 4) & Intermittent Strain-Strangle & 3 & 1 & 5,5 & 5 & 5 & 2,5 \\
\hline 5) & Constant Strain-Strangle & 2 & 1 & 2 & 1 & 2 & 1 \\
\hline 6) & Loudness & 4 & 1 & 1 & 1,5 & 2 & 1,5 \\
\hline 7) & Pitch & 5,5 & 3,5 & 2,5 & 3 & 4,5 & 2,5 \\
\hline 8) & Pitch Breaks & 4 & 1 & 3 & 1 & 3 & 1 \\
\hline 9) & Rate & & & 1,5 & 2 & 1,5 & 5 \\
\hline 10) & Overall Vocal Efficiency & 4,5 & 2 & 7 & 5 & 7 & 2 \\
\hline Ove & rall Severity & moderate & mild & severe & moderate & moderate & mild \\
\hline
\end{tabular}

Table 2 Pre- and post-therapeutic frequency count of strained syllables (\%SS); total number of syllables and rate of speech in SPM for reading and spontaneous speech.

\begin{tabular}{|c|c|c|c|c|}
\hline & \multicolumn{2}{|c|}{ READING } & \multicolumn{2}{|c|}{$\begin{array}{c}30 \text { SEC. SPONTANEOUS } \\
\text { SPEECH }\end{array}$} \\
\hline & Pre & Post & Pre & Post \\
\hline \%SS & $14,8 \%$ & $8,6 \%$ & $15,4 \%$ & $0 \%$ \\
\hline Tótal Syllables & 128 & 128 & 84 & 63 \\
\hline Rate (spm) & 200 & 160 & 190 & 150 \\
\hline
\end{tabular}

Table 1 indicates that while there was some improvement in the reading passage, the improvement was not marked. However, there was an overall improvement for the speech sample and prolonged vowel.

Table 3 Pre- and post laryngographic measures for prolonged $/ i: /$, reading and spontaneous speech. ( $n=$ total number of phonation stretches).

\begin{tabular}{|c|c|c|c|c|c|c|c|}
\hline & \multirow[b]{2}{*}{ Waveform Category } & \multicolumn{2}{|c|}{$\begin{array}{c}\text { Prolonged } \\
\text { /i: } /\end{array}$} & \multicolumn{2}{|c|}{ Reading } & \multicolumn{2}{|c|}{$\begin{array}{l}\text { Spontaneous } \\
\text { Speech }\end{array}$} \\
\hline & & \multirow{2}{*}{$\begin{array}{c}n=23 \\
\text { Pre } \\
13 \%\end{array}$} & \multirow{2}{*}{$\begin{array}{c}n=23 \\
\text { Post } \\
4,3 \%\end{array}$} & \multirow{2}{*}{$\begin{array}{c}n=101 \\
\text { Pre } \\
70,3 \%\end{array}$} & \multirow{2}{*}{$\begin{array}{c}n=126 \\
\text { Post } \\
71,4 \%\end{array}$} & \multirow{2}{*}{$\begin{array}{c}n=35 \\
\text { Pre } \\
77,1 \%\end{array}$} & \multirow{2}{*}{$\begin{array}{c}\mathrm{n}=50 \\
\text { Post } \\
64 \%\end{array}$} \\
\hline A) & Variability per phonation stretch & & & & & & \\
\hline $\begin{array}{l}\text { B) } \\
\text { i) } \\
\text { ii) } \\
\text { iii) } \\
\text { iv) } \\
\text { v) } \\
\text { vi) }\end{array}$ & $\begin{array}{l}\text { Shape of Lx: } \\
\text { Double/multi peaked base } \\
\text { Irregular rise } \\
\text { Double/multi peaked peak } \\
\text { Irregular decline } \\
\text { Exaggerated gradual decline } \\
\text { Sustained amplitude reduction }\end{array}$ & $\begin{array}{r}13 \% \\
0 \% \\
0 \% \\
0 \% \\
0 \% \\
86,9 \%\end{array}$ & $\begin{array}{r}26 \% \\
4,3 \% \\
4,3 \% \\
4,3 \% \\
0 \% \\
0 \%\end{array}$ & $\begin{array}{r}16,8 \% \\
1,9 \% \\
18,8 \% \\
8,9 \% \\
36,6 \% \\
43,5 \%\end{array}$ & $\begin{array}{r}22,2 \% \\
3,7 \% \\
42,8 \% \\
40,5 \% \\
33,5 \% \\
31,7 \%\end{array}$ & $\begin{array}{r}14,2 \% \\
2,8 \% \\
25,7 \% \\
14,2 \% \\
40 \% \\
34,2 \%\end{array}$ & $\begin{array}{r}16 \% \\
8 \% \\
28 \% \\
34 \% \\
28 \% \\
30 \%\end{array}$ \\
\hline C) & Shimmer & $8,7 \%$ & $4,3 \%$ & $58,4 \%$ & $59,2 \%$ & $62,8 \%$ & $56 \%$ \\
\hline & $\begin{array}{l}\text { Fx } \\
\text { Jitter } \\
\text { Abnormal Fx drops }\end{array}$ & $\begin{array}{r}13 \% \\
8,7 \%\end{array}$ & $\begin{array}{r}4,3 \% \\
0 \%\end{array}$ & $\begin{array}{l}44,5 \% \\
27,7 \%\end{array}$ & $\begin{array}{l}43,6 \% \\
26,1 \%\end{array}$ & $\begin{array}{l}40 \% \\
28 \%\end{array}$ & $\begin{array}{l}42 \% \\
25 \%\end{array}$ \\
\hline E) & Vocal Fry & $0 \%$ & $0 \%$ & $22,7 \%$ & $23,8 \%$ & $17,1 \%$ & $24 \%$ \\
\hline
\end{tabular}

Die Suid-Afrikaanse Tydskrif vir Kommunikasieafwykings, Vol. 32, 1985

b) FREQUENCY OF STRAINED VOCAL BEHAVIOURS (\%SS) AND RATE OF SPEECH (SPM):

Table 2 indicates a reduction in \%SS post-therapeutically, as well as a reduction in overall rate of speech for both the reading and speech samples.

OBJECTIVE EVALUATIONS

a) LARYNGOGRAPHIC ANALYSIS:

A summary of the results for the prolonged (i:), reading and spontaneous speech samples on each category of the laryngograph is presented in Table 3. A frequency count for each type of waveform per phonation stretch is expressed in terms of a percentage. 
The most noticeable change for all three voice samples can be seen in the amplitude of the wave forms. Table 4 indicates the change in average amplitude pre- and post-therapeutically.

Table 4 Changes in average amplitude of waveforms preand post-therapeutically.

\begin{tabular}{|l|c|c|c|c|c|c|}
\cline { 2 - 5 } \multicolumn{1}{c|}{} & \multicolumn{2}{c|}{$\begin{array}{c}\text { Prolonged } \\
/ \mathrm{i}: /\end{array}$} & \multicolumn{2}{c|}{ Reading } & \multicolumn{2}{c|}{$\begin{array}{c}\text { Spontaneous } \\
\text { Speech }\end{array}$} \\
\cline { 2 - 4 } & Pre & Post & Pre & Post & Pre & Post \\
\hline $\begin{array}{l}\text { Averagc } \\
\text { Amplitude } \\
\text { in mm. }\end{array}$ & $10 \mathrm{~mm}$ & $25 \mathrm{~mm}$ & $10 \mathrm{~mm}$ & $16 \mathrm{~mm}$ & $13 \mathrm{~mm}$ & $17 \mathrm{~mm}$ \\
\hline
\end{tabular}

\section{b) FIBEROPTIC EXAMINATION:}

Normal. symmetrical vocal folds were evident at rest and during deep breathing pre- and post-therapeutically. Both the true and false vocal folds remained abducted. Figures la and $b$ indicate the physiological alteration of the vocal folds for the prolonged vowel preand post-therapeutically.

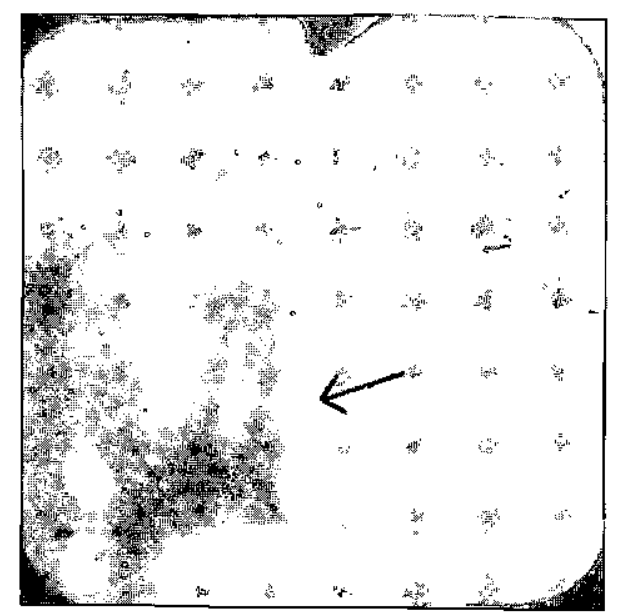

Figure la

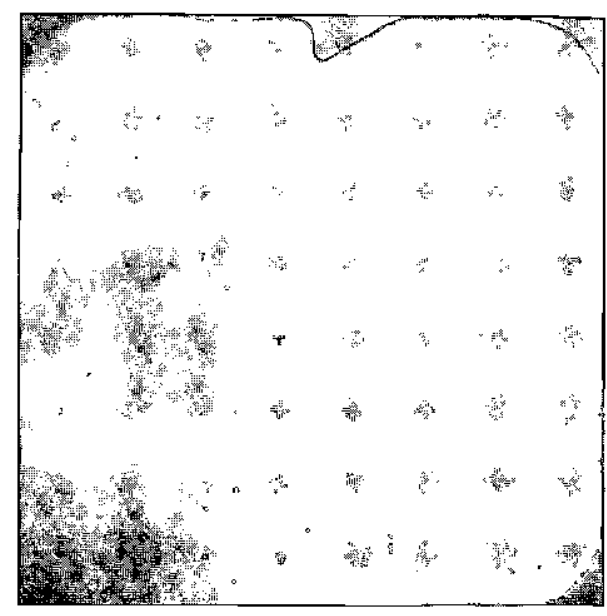

Figure lb

Figure la \& $1 \mathrm{~b}$. The physiological alteration of the vocal folds during the prolonged /1:/ pre- (a) and post- (b) therapeutically.

Figure la reveals that pre-therapeutically the vocial folds were tightly adducted with the false folds approximating one another in an asymmetrical fashion. The left fold was tensed, had more bulk and was more adducted than the right fold. Figure lb shows that posttherapeutically the true cords were not tightly adducted and a chink was visible along their inner border. The false folds approximated but were symmetrical. On subjective evaluation, the vowel in Fig. la was perceived as having a tight, strained hoarse quality, while in Fig. lb, it was perceived as having a breaking quality.

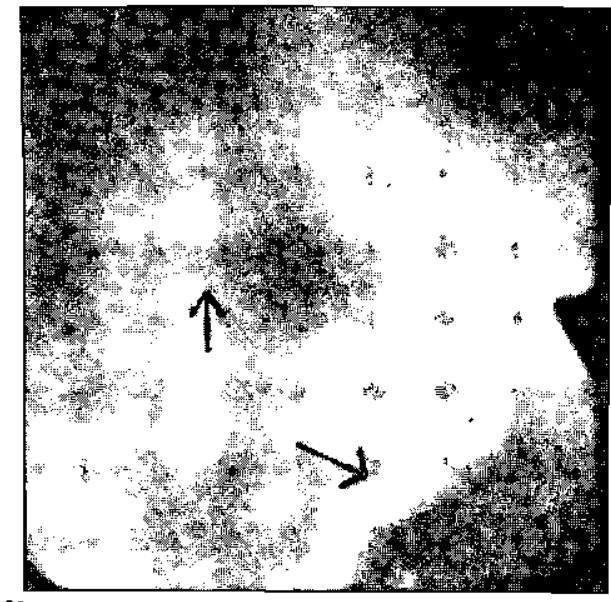

Figure 2b

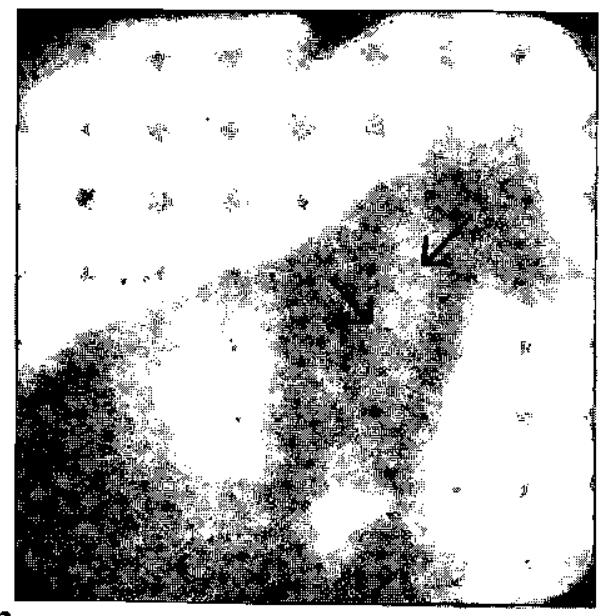

Figure 2a

Figures 2a \& 2b. The vocal folds during the production of the word / Iowd/ pre and post therapeutically respectively.

Figures $2 \mathrm{a}$ and $\mathrm{b}$ reveal an alteration in the physiology of the vocal folds for spontaneous speech pre- and post-therapeutically. In Fig. 2a pre-therapeutically, total arrest of the glottis was apparent, where the false folds were tightly adducted in the midline, and obscured the view of the true vocal folds. Tension was evident posteriorly as adjustments in the arytenoid cartilages were made. Subjectively, a tight squeezed, laryngealized quality was evident. Posttherapeutically, less tension in the glottis was present. The true cords were not tightly adducted and a visible chink was present between the cords. While the false folds approximated they did not adduct. This was perceived as having a laryngealized quality on subjective evaluation.

Finally, Table 5 summarises the results obtained from both the subjective and objective evaluations after the therapy period.

Table 5 Overall summary of pre- and post-therapeutic measures for all three voice samples.

\begin{tabular}{|l|c|c|c|}
\cline { 2 - 4 } \multicolumn{1}{c|}{} & $\begin{array}{c}\text { Subjective } \\
\text { Evaluation }\end{array}$ & $\begin{array}{c}\text { Laryngograph } \\
\text { Tracings }\end{array}$ & $\begin{array}{c}\text { Fiberoptic } \\
\text { Examination }\end{array}$ \\
\hline Reading & + & + & \\
\hline $\begin{array}{l}\text { Spontancous } \\
\text { specch }\end{array}$ & ++ & + & ++ \\
\hline Prolonged $/ \mathrm{i}: t$ & ++ & ++ & ++ \\
\hline
\end{tabular}

Key: $+=$ sight improvemen

The South African Journal of Communication Disorders, Vol. 32, 1985 


\section{DISCUSSION}

The results of the study indicated some improvements on all three voice samples for both subjective and objective measures posttherapeutically. The improvement was most evident in a reduction in adductor spasms, strained strangled phonation and overall vocal tension. Subjectively, the voice was judged as less tense, and a reduction in \%SS was evident on the reading and speech samples. The reduction in exaggerated gradual decline and increase in wave form amplitude on the laryngographic tracing seemed to indicate less tension and freer vibration of the vocal cords (Traill 1984). The fiberoptic examination revealed a chink between the true folds which were not adducted as tightly as they had been previously. Izdebski, Dedo, Shipp and Flower (1981) write that the characteristic identified as overpressure (i.e. strain) is typical of spastic dysphonia, and thus the reduction in strain observed in this study could be considered a positive index of treatment outcome.

Lerman (1980) found that in spastic dysphonia, the over adducted vocal folds impeded the airflow, thus disrupting the delicate balance between airflow and glottic resistance which is necessary to produce acceptable phonation. The reduced rate of speech inherent in this therapy programme seemed to induce voluntary control over the adductor laryngeal muscles which facilitated the co-ordination of the muscles for phonation. Sustained phonation and easy initiation of phonation were found to eliminate the tight adduction in the cords and the effortful forced phonation in this study.

Adams (1975) and Schwartz (1976) feel prolonged speech facilitates glottal vibration by integrating sub-glottal air pressure, glottal resistance, supraglottal pressure, correct timing, smooth initiation and maintenance of airflow. Stuttering occurred when this integration was disturbed. This imbalance was observed in the present study which further lends support to the similarity in vocal fold physiology of stuttering and spastic dysphonia, and to the applicability of a 'fluency based' programme with an adductor spastic dysphonia client. The study also showed that behaviour therapy can be applied to consciously manipulate vocal cord behaviour, thus supporting the views held by Boone (1977), and Mowrer and Case (1982).

A rough laryngeal tone was still noted on the post-therapy subjective evaluation for reading and spontaneous speech. This was confirmed by the laryngographic tracings and the presence of false fold approximation on the fiberoptic examination. Boone (1977) writes that a rough vocal quality is caused by aperiodic vibration, and ventricular phonation may be caused by the ventricular folds lying in close contact with the superior surfaces of the true cords. Traill (1984) feels that the interference of the false folds above alters their tension and interferes with their movement. These perceptive characteristics showed up as irregular $\dot{L} x$ waveforms on the laryngographic tracings, where shimmer, jitter and irregular peaks and declines were still observed post-therapeutically. Wechsler (1977) found that shimmer, jitter and irregular fold vibration could occur in normal speakers but Horii $(1980)$ found these features were more extensive in pathological speakers. The high percentage of the above three features on the laryngographs of this subject, indicated some pathology to be remaining in the voice. The writers contend, that while the 'fluency-based' programme was effective in altering the mode of laryngeal vibration, it did not sufficiently reduce the contribution of the false folds during phonation which resulted in the harsh ventricular vocal quality. Since the technique employed in this study has been effective in modifying both true and false fold activity in stutterers, perhaps further practice is needed with the techniques in spastic dysphonia.

Vocal tremor was still evident post-therapeutically on the subjective assessment of all three voice samples. The writers speculate that irregular waveshapes, particularly the irregular base or rise in the laryngographic tracings, may be related to the tremulous vocal quality. The maintenance of the tremor in this subject is interesting since McCall (1975) noted that tremor in the voice of stutterers decreased when the mode of phonation was altered to induce fluent speech. The writers feel that the laryngeal adjustments necessary for maintaining continuous phonation might have caused the tremor, due to the novel mode of phonation to which the larynx had been subjected. Perhaps further practice with the therapy technique might have reduced the amount of vocal tremor.

An alteration in modal pitch occurred on the post-therapeutic measures. Pre-therapeutically, a drop in the Fx tracing of the laryngograph coincided with a tight, strained voice and exaggerated gradual abduction of the vocal cords. Aronson et al. (1968) found that a low modal pitch coincided with hyperadducted vocal cords in more severe forms of spastic dysphonia. These features were more prevalent in the subject prior to therapy and his voice disorder was judged as being more severe. Post-therapeutically, a reduction in the percentage of Fx drops and exaggerated gradual decline on the laryngographic analysis were evident. A decrease in \%SS and overall vocal severity was noted on subjective evaluation. Thus, the subject's symptomatology confirmed the findings of Aronson et al. (1968) that in milder forms of spastic dysphonia, fleeting moments of strained harshness are evident with the pitch not being severely affected.

The results of this study indicate some discrepancy across the different voice samples, as well as in the subjective and objective evaluations. The prolonged vowel showed a greater improvement than the reading and speech samples which is an interesting finding, since studies on spastic dysphonia have indicated that the voice deteriorates in the contextual, communicative functions of speech (Boone 1977; Aronson 1980). In addition, studies have shown that the voice deteriorates when voiced voiceless transitions need to be made (Dedo and Shipp 1980).

Various factors could have been related to the discrepancy between the subjective and laryngographic results for reading and spontaneous speech. Progress in therapy was slow and the phase of transfer had not yet been reached. Boone (1977) maintains that with spastic dysphonia, much time must be spent in working on environmental factors to allow the patient to phonate in a normal, relaxed way in various environmental situations. The discrepancy on the reading and speaking analysis may have been the result of the subject's difficulty in maintaining the continuous phonation on reading throughout the therapy programme.

The phase of follow-up included in the stutter-free speech programme has been found to be essential with stutterers (Shames and Florance 1980). Regression after treatment might occur and therefore the need for longer treatment to maintain fluency in stutterers has been emphasized (Perkins et al 1974; Shames and Florance 1980). Wechsler (1977) found that in voice disorders, when the larynx appeared to have improved, but no improvement on $\mathrm{Lx}$ waveforms was noted, further treatment and long-term follow-up was indicated lest relapse occurred. The findings of this study lend support to Wechsler (1977) since improvement was evident subjectively, but little change was determined on the laryngographic waveforms. Boone (1977) feels that long-term follow-up procedures are essential in spastic dysphonia which has such a high rate of symptom relapse.

\section{CONCLUSION}

A 'fluency-based' therapy programme conventionally used for stutterers was found to be effective in altering the vocal behaviours of 
a spastic dysphonic client. The writers feel that the therapy resulted in a reduction of vocal fold hyperadduction. This is in agreement with Perkins (1971) as cited by Reed (1980) stating that regardless of etiology, therapy for spastic dysphonia could be based on a functional analysis of vocal fold behaviour, where the knowledge of laryngeal function is used to achieve a more efficient voice.

\section{ACKNOWLEDGEMENTS}

The writers wish to thank Prof. A. Traill, Department of Linguistics, University of the Witwatersrand, Johannesburg, for his assistance, guidance and time in conducting the objective measures.

\section{REFERENCES}

Adams, M.R. Vocal Tract Dynamics in Fluency and Stuttering. In Vocal Tract Dynamics and Dysfluency. Webster, L.M. and Furst, L.C. (Eds.), Speech and Hearing Institute, New York, 1975.

Aronson, A.E. Clinical Voice Disorders: An Interdisciplinary Approach, Thieme. Stratton, New York, 1980

Aronson, A.E., Brown, J.R., Litin, E.M., and Pearson, J.S. Spastic Dysphonia I: Voice Neurologic and Psychiatric Aspects. J. Speech. Hear. Disord., 33, 203-218, 1968.

Boone, D.R. The Voice and Voice Therapy, 2nd. Ed., Prentice Hall, New Jersey, 1977.

Chapey, R. and Salzberg, D. The Speech Clinician's Use of Fiberoptics in Indirect Laryngoscopy. J. Comm. Disord., 14, 87-90, 1981.

Dedo, H.H. and Shipp, T.S. Spastic Dysphonia: A Surgical and Voice Therapy Treatment Programme. College Hill Press, Houston, 1980.

Fairbanks, G. Voice and Articulation Drillbook. Harper and Brothers, New York, 1940.

Hirano, M. Clinical Examimation of Voice. Springer Verlag, New York, 1981.

Horii, Y. Vocal Shimmer in Sustained Phonation. J. Speech. Hear. Res. 23, 202-209, 1980.

Ingham, R.J. and Andrews, G. Behaviour Therapy and Stuttering: A review. J. Speech. Hear. Disord., 38, 405-441, 1973.

Izdebski, K.: Dedo, H.H.; Shipp, M.D. and Flower, M. Postoperative and Foliow-up Studies of Spastic Dysphonia Patients Treated by Recurrent Laryngeal Nerve Section. Otolaryngol. Head. Neck Surg. 89, 96-101, 1981.

Kelman, A.W. Vibratory Patterns of the Vocal Folds. Folia Phoniat. $33(2), 73-100,1981$.

Lerman, J.W. Disorders of Phonation and their Management. Ear, Nose and Throat J. 59, 62-72, 1980.

Luchsinger, R. and Arnold, G.E. Voice - Speech - Language. Wordsworth Publishing Co., California, 1965.

McCall, G.N. Spasmodic Dysphonia and the Stuttering Block. In Vocal Tract Dynamics and Dysfluency Webster, L.M. and Furst, L.C. (eds). Speech and Hearing Institute, New York, 1975.

Miller, S. Airflow Therapy Programmes. Facts and/or Fancy. $J$. Fluency Dis. 7, 187-202, 1982.

Mowrer, D.E. and Case, J.L. Clinical Management of Speech Disorders. Aspen Systems Corporation U.S.A. 1982.

Perkins, W.H.: Rudas, J.; Johnson, L.; Michael, W.G. and Curlee, R.F. Replacement of Stuttering with Clinical Effectiveness III. J. Speech, Hear. Disord., 39, 416-428, 1974.

Reed, G.G. Voice Therapy: A Need for Research. J. Speech Hear Disord. , 45 (2), 157-171, 1980

'Reich, A. and Till, J. Phonatory and Manual Reaction Time of Women With Idiopathic Spasmodic Dysphonia. J. Speech Hear. Disord., 26 (1), 10-17, 1983.
Salamy, J.N. and Sessions, R.B. Spastic Dysphonia. J. Fluency Dis. 5, 281-290, 1980.

Schwartz, M. Stuttering Solved. J.B. Lipincott, Philadelphia, New York, 1976.

Shames, G.H. and Florance, C.L. Stutter-Free Speech. Charles E. Merrill, Columbus, Ohio, 1980.

Traill, A. Personal Communication. Department of Linguistics, University of the Witwatersrand, Johannesburg, 1984.

Wechsler, E. A Laryngographic Study of Voice Disorders. Brit. J. Dis. Comm. 12, 19-22, 1977.

Wilson, D.K.: Voice Problems of Children 2nd ed. Williams and Wilkins, Baltimore, 1979.

Wolk, L. Spastic Dysphonia: a case report S.A.J. Commun. Disord., 2, 3-18, 1980.

\section{APPENDIX 1}

READING AND SPONTANEOUS SPEECH SCALE

Parameter

1) Laryngeat Tension

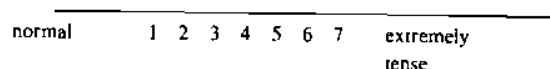

2) Laryngeal Tone

tense

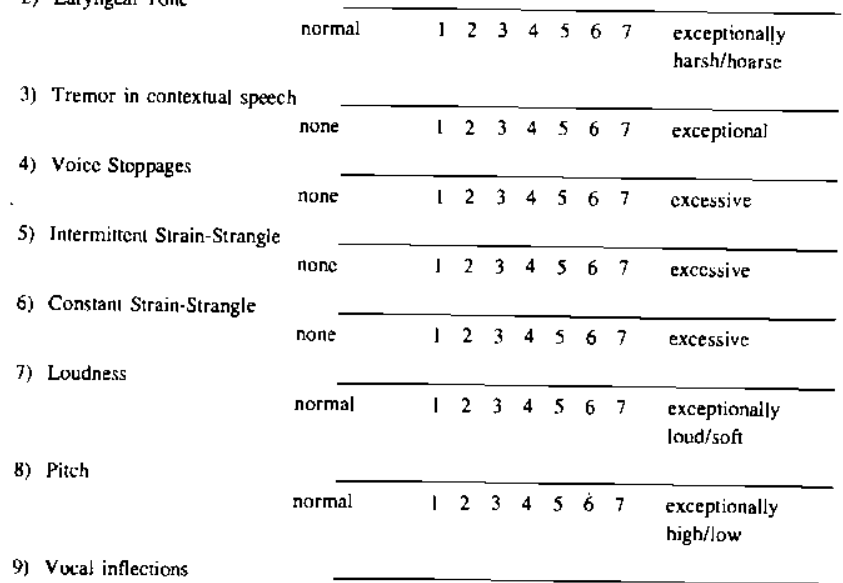

9) Vucal inflections

10) Pitch breaks to higher pitches

11) Rate

normal $\quad$\begin{tabular}{lllllllll}
\hline & 2 & 3 & 4 & 5 & 6 & 7 & monotonous
\end{tabular}

12) Overall veral efficiency

none $\begin{array}{llllllll}1 & 2 & 3 & 4 & 5 & 6 & 7 & \text { excessive }\end{array}$

13) Nanuralness

nurmal $\begin{array}{lllllllll} & 1 & 2 & 3 & 4 & 5 & 6 & 7 & \begin{array}{l}\text { exceptionally } \\ \text { fast/slow. }\end{array}\end{array}$

$\begin{array}{llllllllll}\text { cfficient } & 1 & 2 & 3 & 4 & 5 & 6 & 7 & \text { incfficient }\end{array}$

\section{APPENDIX 2}

Surnmary of categories analyzed on laryngographic analysis adapted from 'Boone (1977), Horii (1980) and Traill (1984).

\begin{tabular}{|l|l|}
\hline Lx waveform & $\begin{array}{l}\text { provides information on vocal fold vibratory } \\
\text { cycle. } \\
\text { maintenance of a stable vibratory pattern. } \\
\text { provides a basis for observing the nature of, con- } \\
\text { tact and separation time of the vocal folds. } \\
\text { changes in adjacent wave amplitudes. } \\
\text { b) Waveshape } \\
\text { vocal pitch. } \\
\text { cycle to cycle variations in frequency. Cor- } \\
\text { responds with shimmer on Lx. Shimmer and jitter } \\
\text { correlate with rough/hoarse voice. } \\
\text { exaggerated drops in Fx tracing. }\end{array}$ \\
\hline a) Jitter &
\end{tabular}




\section{Philips Hearing Aid Services}

A Division of S.A. Philips (Pty) Ltd.

\section{hearing aids \\ Amplaid audiometers}

em m m m

Head Office 1005 Cavendish Chambers, 183 Jeppe Street, P.O. Box 3069, JOHANNESBURG.

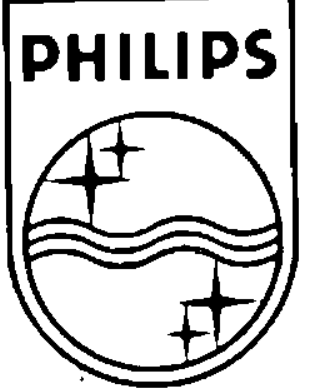

